UDC 378:811:004

Natalia V. Maiier

Associate Professor, Doctor of Pedagogy, Professor of the Department of Foreign Language Teaching

Methodology, and Information and Communication Technologies

Kyiv National Linguistic University, Kyiv, Ukraine

ORCID ID 0000-0001-7074-8135

teacher123@ukr.net

\title{
DISTANCE LEARNING TECHNOLOGIES IN ORGANIZING SELF-STUDY WORK OF STUDENTS MAJORING IN PHILOLOGY
}

\begin{abstract}
In this article, on the basis of the analysis of didactic potentialities of three kinds of distance learning technologies (case technology, Internet technology, TV technology), the feasibility of integrating case and Internet technologies to design an "electronic case" as a means of students' self-studying in e-learning of foreign languages and cultures is substantiated. The content of educational, monitoring, motivating and informative functions of the "electronic case" in self-studying is defined. The constituent features of the "electronic case" are described. The structure examples of the "electronic case" and its content for developing business letter writing and reading skills are given. To create an "electronic case" a course management system Moodle should be used as its educational potential enables implementation of the suggested requirements for its designing.
\end{abstract}

Keywords: distance learning technologies; electronic case; foreign languages and cultures; students' self-study work.

\section{INTRODUCTION}

Problem statement. An important part of the educational process of teaching foreign languages in tertiary educational establishments is students' self-studying. However, its organization is one of the most difficult functions of the teacher. The effectiveness of students' self-studying foreign languages and cultures is associated with the use of information and communication technologies that affect the choice of forms, methods and techniques of its organization. The latter, in their turn, determine the content and types of students' activities for autonomous mastering foreign language communicative competence at extracurricular time.

Analysis of recent research studies. The peculiarity of the current state of computerization of teaching foreign languages is an increased interest in theoretical studies and practically designed methods and tools of using distance learning technologies to organize students' self-studying. Thus, the expediency of using the case technology as a set of traditional educational materials for teaching writing to foreign experts and students of nonphilological profile [1] was grounded. Also, traditional lesson and case technologies were integrated into teaching French to students majoring in philology; the case was the electronic guide "Le français de tous les jours" for self-study work [2]. G. Vishnevskaya suggested using the Internet technology for teaching foreign languages to extracurricular students of nonlinguistic majors [3], while L. Zhuk perceived the implementation of Internet technologies as the teacher's personal web site as the central medium of organizing students' self-studying foreign languages with the help of online resources and Internet communication tools [4]. However, researchers focus primarily on one type of distance learning technologies to organize students' learning activities for forming their foreign language communicative competence or its certain parts. But the potentiality of integrating distance learning 
technologies into the process of organizing students' self-studying foreign languages and cultures still has not been adequately studied.

The aim of the article. In view of the above, the aim of this article is to highlight opportunities of integrating distance learning technologies into students' autonomous elearning foreign languages and cultures.

\section{THEORETICAL BACKGROUND}

Several theoretical and practical studies are devoted to aspects of realizing blended learning and choosing its optimal models for foreign language classrooms at tertiary institutions [5], [6], [7]. The scientific approaches, didactic principles, tools, methods and forms of blended learning at higher educational establishments are grounded [8].

The idea to integrate distance learning technologies into the organization of selfstudying foreign languages and cultures is based on my experience of teaching students of linguistic and non-linguistic majors.

Distance learning technologies are technologies that can organize targeted and methodical management of students' educational and cognitive activities, and are based on the use of a wide range of traditional, information and communication technologies [9, p. 11].

The following types of distance learning technologies implemented in the foreign language teaching are distinguished: case technology, Internet technology, TV technology [10], [11], [12], [13], [14].

The case technology in students' self-studying foreign languages is implemented by a special set of educational materials called "cases" which usually does not include the use of information and communication technologies for their development and presentation to students. Traditionally, the implementation of case technologies in the educational process is associated mainly with the desire to preserve and use the rich variety of traditional teaching methods and techniques. As a rule, students receive all necessary course materials directly from the teacher and work with them autonomously, doing the given tasks during extracurricular work or in the classroom under the supervision of the teacher. There also may be provided teacher's counselling to students in various modes. However, at the present stage of informational education, researchers believe [15] that the case technology exists to provide students with electronic information and educational resources as a set of special course materials designed for self-studying, including various media, with which I agree. The case technology should be used for students' self-study work on mastering foreign language communicative competence and its single elements.

The Internet technology is based on the use of global and local computer networks to provide students with necessary educational materials. During self-studying of foreign languages and cultures, students acquire communicative competence, interacting with their teacher, other students, or with online e-learning tools. Using didactic possibilities of the Internet (access to the newest authentic materials, socio-cultural information, direct contact with native speakers, participation in international projects, conferences, video conferences, chats, virtual digital libraries, online journals, databases and data banks, website, blog, forum, virtual classroom, bulletin board, network multimedia training courses) provides opportunities for the development of students' foreign language skills in different speech types.

The TV technology is a distance learning technology with the help of which educational materials are transmitted through satellite television or TV systems. The TV technology enables group or individual watching and listening to video lectures provided by a discipline syllabus, as well as presentation of educational video materials on particular topics. This distance learning technology is most motivated when used for students' self-study work on their foreign language listening skills. 


\section{RESEARCH RESULTS}

Today, particular importance is attached to exploring the ways of integrating distance learning technologies into educational processes, to fully make use of their didactic potentialities at appropriate stages, and achieve the goals of teaching and learning during students' self-studying foreign languages and cultures.

One of the solutions of this problem is the combination of several distance learning technologies to develop means of self-mastering foreign language communicative competence at extracurricular time. In particular, the integration of the case and Internet technologies enables the creation of the "electronic case", which is an e-learning tool available on the Internet, contains a set of course and reference materials to extend knowledge, acquire and improve language and speech skills, and provides self-management of students' self-studying activities.

In the organization of students' self-studying of foreign languages and cultures, the "electronic case" possesses several functions:

1) the educational function, which is the main one and provides mastering course materials necessary and sufficient for acquiring knowledge, language and speech skills at a certain stage of learning within a certain theme;

2) the monitoring function, which is implemented in students' self-assessment and teacher's mediated monitoring of e-learning process, its results, and possessing skills and abilities;

3) the motivating function, which is ensured by professional aiming of educational materials at making students' work interesting and meeting their needs in the future professional activities;

4) the informative function, which is realized by filling the "electronic case" with necessary and sufficient information and reference materials to enable students' operating independently, save their time spent on searching for information to perform the given tasks, which promotes more rationally organized self-education.

The effectiveness of self-mastering foreign language communicative competence at extracurricular time depends on proper structuring the "electronic case" and its content.

The "electronic case" can have a modular structure, or consist of parts and sections each of which is a relatively independent component which provides students with the necessary and sufficient portion of course and reference materials for a particular purpose at the appropriate stage of mastering foreign language communicative competence.

The content of the "electronic case" is conditioned by variations of students' educational and cognitive activities in mastering certain speech skills. That's why "electronic cases" for developing listening, reading, speaking and writing skills are designed, and facilitate integrated formation of socio-cultural and strategic competences as well as interrelated mastering of language, speech and translation skills. Exercises and tasks of the "electronic case" are subordinated to stages of language and speech skills development in a particular speech type as defined in FLT methodology. Also, the content and structure of the "electronic case" include information and reference materials to help students learn at their extracurricular time. The introduction summary of the "electronic case" will introduce students to peculiarities of working with course and other materials.

The following are examples of structures of the "electronic cases" designed for different purposes. 


\section{Example 1.}

The structure of the "electronic case" for teaching students written business communication in a foreign language

Introduction summary.

Part 1. Course and reference materials (grammar guide, punctuation guide, rules of transliteration of the Ukrainian proper names into foreign languages, etc.).

Part 2. Speech patterns and vocabulary.

Part 3. The preparatory stage (exercises for forming skills of predicting the rules of writing a business letter and its layout; for formulating the rules of business letters writing; for building skills of using correct layout of a business letter; for monitoring and checking the degree of mastering course material on how to write business letters; for improving spelling and punctuation skills; for improving vocabulary and grammar skills in reading and writing).

Part 4. The principal stage (exercises for developing skills of reading for detail; for building skills of writing business letters; for assessing the level of reading and business letter writing skills).

\section{Example 2.}

Note that the purpose of teaching reading skills, the use of teaching methods, learning tools, and designing series of exercises depend on a type of reading comprehension. Therefore, it is advisable to use reference materials in each part of the "electronic case".

The structure of the "electronic case" for developing students' foreign language reading skills Introduction summary.

Part 1. Exercises and tasks for developing skimming reading skills.

Reference materials (dictionary, socio-cultural commentary, etc.).

Part 2. Exercises and tasks for developing scanning reading skills.

Reference materials.

Part 3. Exercises and tasks for developing reading for detail skills.

Reference materials.

The course and reference materials of the "electronic case" should be self-sufficient and accessible to students in real-time operation mode. Self-sufficiency of educational materials of the "electronic case" allows the proper learning which is actualized in a series of exercises and tasks aimed at forming different speech competences and provide the required number of reference materials that enable students' self-study work, without teacher's support or resorting to other resources.

It is well-known that an important component of any tutoring system is control. Therefore, a prerequisite for effective self-studying foreign languages and cultures is providing opportunities for students' self-assessment of their learning process and its results, and for teacher's step-by-step mediate monitoring. For this purpose, during students' selfstudy work with an "electronic case", a computer-assisted assessment should be used [16, p. 57] which involves the use of tests as a means of students' self-studying and self-assessing, and a means of teachers' step-by-step indirect monitoring. In this way, the self-studying student can assess their own progress, become aware of their errors and, on this basis, plan educational actions to move to the next stage / next part of e-learning, or can re-study the necessary course material for its better mastering. That is to say, the student has an opportunity to create their own educational trajectory (the student's individual educational route to reach the goal according to their own individual strategies of course material mastering, abilities, personal motives, needs [17, p. 125]), to self-correct it in accordance with self-assessment results; and the teacher has an opportunity to indirectly monitor the student's educational and cognitive activities, and assist him/her in updating his/her individual trajectory. 
The "electronic case" should have a high level of interactivity, means "the ability of computer-assisted learning to provide verbal or nonverbal educational dialogue between man and computer, resulting in the exchange of course materials and the results of its study [18, p. 76]". Learning tools created with the help of information and communication technologies can be considered interactive when they realize the following exponents: non-linear access to educational information; efficiency of subject-subject and subject-object feedback; communicative interaction between the subjects of learning; adaptation of tutoring system to the individual characteristics of students; implementation of strategies for managing learning activities of students during self-studying; ensuring different levels of students' autonomy while teaching, and others. Interactivity should provide students with communicative interaction with the "electronic case", allowing the exchange of information, correction, communication with the teacher and other students with the purpose of reviewing / checking up the performed tasks, individual consultations in various modes.

To sum up, the "electronic case" must meet the following requirements: structurization (allotment of parts, sections), self-sufficiency of course materials, appliance of computerassisted assessment and monitoring, high level of interactivity. To design the "electronic case" one should use a course management system Moodle, didactical potentialities of which enable the implementation of the above requirements. In addition, Moodle gives the possibility to provide the multivariate presentation of educational information, design of exercises and tasks with various modules of students' activities, multiple revision of course materials, structurization of content, implementation of individual learning trajectories, privacy of teaching, creation and use of assessment system within the "electronic case", teacher's monitoring students' systematic activities and time of their self-study work with the "electronic case" content.

\section{CONCLUSION AND FURTHER RESEARCH PROSPECTS}

The integration of the case and Internet technologies, particularly the creation on their basis of the "electronic case", is a promising model of students' self-study work on mastering intercultural competence, and it enables the implementation of blended learning with its characteristic principles of complementing the educational process with the elements of online teaching. The "electronic case" is an e-learning tool for students' extracurricular selfstudy work. It is advisable to design "electronic cases" to develop students' skills in different types of speech activities. In the organization of students' foreign language and culture selfstudy work, the "electronic case" performs educational, evaluative, motivating and informative functions. The effectiveness of students' extracurricular work depends on structuring educational materials and content of the "electronic case". The content is determined by varieties of students' activities in mastering certain communicative skills. The "electronic case" content includes exercises, tasks, information and reference materials to help students learn independently at extracurricular time, and the explanatory note to review the features of this learning tool. The "electronic case" exercises and tasks conform to stages of building certain communicative skills as they are defined in the foreign language teaching methodology. Substantiation of the structure of electronic educational course materials which include different "electronic cases" for teaching foreign languages is the prospect of further research. 


\title{
REFERENCES (TRANSLATED AND TRANSLITERATED)
}

[1] T. Bazvanova, "Training of foreign students and specialists of non-philological profile with business letters using remote technologies", M. S. thesis, Pushkin St. Russian Language Univ., Moscow, Russia, 2005. (in Russian)

[2] E. Efimkina, "Methodology of using distance educational technologies in teaching the French language to students of linguistics", M. S. thesis, Dobrolyubov St. Linguistic Univ., Nizhniy Novgorod, Russia, 2010. (in Russian)

[3] G. Vishnevskaya, "The introduction of distance technologies in the process of teaching foreign languages to part-time students of non-linguistic universities", Izvestiya Penzenskogo gosudarstvennogo pedagogicheskogo universiteta im. V. G. Belinskogo, № 24., pp. 589-592, 2004. (in Russian)

[4] L. Zhuk, "Internet technologies as a means of organizing independent work of students of technical universities: on the teaching material of a foreign language", M. S. thesis, St. Petersburg Polytechnic Univ., St. Petersburg, Russia, .2006. (in Russian)

[5] V. Barkasi and S. Barkasi, "Blended learning usage in teaching foreign languages in the universities". «Young Scientist». № 2 (17), pp. 203-206, 2015. (in Ukrainian)

[6] N. Zemlianska, "Application of blended learning in teaching foreign languages at high school", The journal of humanities of the SHEE "Pereyaslav-Khmelnytskyi State Pedagogical University named after Hryhoriy Skovoroda": collection of scientific works, Ed. 36, pp. 228-236, 2015. (in Ukrainian)

[7] B. Shunevych, "Method of blended learning teaching of forign languages at high school", Naukovi zapysky Natsional'noho universytetu "Ostroz'ka akademiya": Ser.:Filolohichna, vol. 11, pp. 542-548, 2009. (in Ukrainian)

[8] O. Korotun, "Methodological bases of blended learning in the higher education", Information Technologies in Education, № 3, pp. 117-129, 2016. (in Ukrainian)

[9] K. Kozhuhov, "Pedagogical model of the application of distance technologies in the process of forming the methodical competence of the future teacher (on the material of the discipline "Theory and methodology of teaching foreign languages")", Extended abstract of M. S. thesis, Kursk State Univ., Kursk, Russia, 2008. (in Russian)

[10] E. Polat, Distantsionnoe obuchenie. Moscow, Russia: Vlados, 1998. (in Russian)

[11] A. Hutorskoy "Distance learning and its technologies" [Online]. Available: http: // www.computerra.ru/compunity/edujob/20277/. Accessed on: April 11, 2017 (in Russian)

[12] J. Gilbert et al., Blended learning in English language teaching: course design and implementation. London, UK: British Council, 2013. (in English)

[13] C. A. Ochoa Alpala, and E. E. Roberto Flórez, "Blended learning in the teaching of English as a foreign language: an educational challenge", HOW, vol. 18, no. 1, pp. 154-168, 2011. (in English)

[14] O. Tarnopolsky, Constructivist blended learning approach to teaching English for specific purposes. London, UK: Versita, 2012. (in English)

[15] S. Agaponov, Z. Dzhamashvili, Sredstva distantsionnogo obucheniya: metodika, tehnologiya, instrumentariy. St. Petersburg, Russia: BHV-Peterburg, 2013. (in Russian)

[16] T Koval'., S. Sysoyeva, L. Sushchenko, Pidhotovka vykladachiv vyshchoyi shkoly: informatsiyni tekhnolohiyi u pedahohichniy diyal'nosti. Kyiv, Ukraine: Vyd. tsentr KNLU, 2009. (in Ukrainian)

[17] P. Syisoev, "Training on an individual trajectory", Yazyik i kultura, № 4(24), pp. 121-131, 2013. (in Russian)

[18] E. Mashbits, V. Andrievskaya, E. Komissarova, Dialog v obuchayuschey sisteme. Kyiv, Ukraine: Vischa shkola, 1989. (in Russian)

Матеріал надійшов до редакиї 15.04.2017 p.

\section{ТЕХНОЛОГІЇ ДИСТАНЦЙНОГО НАВЧАННЯ В ОРГАНІЗАЦІї САМОСТІЙНОЇ РОБОТИ СТУДЕНТІВ МОВНИХ СПЕЦІАЛЬНОСТЕЙ}

\author{
Майєр Наталія Василівна \\ доцент, доктор педагогічних наук, професор кафедри методики викладання іноземних мов й \\ інформаційно-комунікаційних технологій \\ Київський національний лінгвістичний університет, м. Київ, Україна \\ ORCID ID 0000-0001-7074-8135 \\ teacher123@ukr.net
}




\begin{abstract}
Анотація. У статті на основі аналізу дидактичних можливостей трьох видів дистанційних технологій (кейс-технології, Інтернет-технології, ТВ-технології) доведена доцільність інтегрувати кейс-технологію та Інтернет-технологію для розробки «електронного кейсу» як комп'ютерного засобу навчання для самостійної роботи студентів 3 іноземних мов i культур. Визначено зміст навчальної, контролюючої, мотивуючої й інформативної функцій «електронного кейсу» у самостійній роботі студентів. Описано особливості контенту «електронного кейсу». Наведено приклади структури «електронного кейсу» і його змісту для розвитку вмінь іншомовного ділового писемного спілкування й умінь читання. Для створення «електронного кейсу» доцільно використовувати систему управління навчанням Moodle, дидактичні можливості якої дозволять реалізувати сформульовані у статті вимоги до його розробки.
\end{abstract}

Ключові слова: дистанційні технології; електронний кейс; іноземні мови і культури; самостійна робота студентів.

\title{
ТЕХНОЛОГИИ ДИСТАНЦИОННОГО ОБУЧЕНИЯ В ОРГАНИЗАЦИИ САМОСТОЯТЕЛЬНОЙ РАБОТЫ СТУДЕНТОВ ЯЗЫКОВЫХ СПЕЦИАЛЬНОСТЕЙ
}

\author{
Майер Наталия Васильевна \\ доцент, доктор педагогических наук, профессор кафедры методики преподавания иностранных языков и \\ информационно-коммуникационных технологий \\ Киевский национальный лингвистический университет, г. Киев, Украина \\ ORCID ID 0000-0001-7074-8135 \\ teacher123@ukr.net
}

\begin{abstract}
Аннотация. В статье на основе анализа дидактических возможностей трёх видов дистанционных технологий (кейс-технологии, Интернет-технологии, ТВ-технологии) доказана целесообразность интегрирования кейс-технологии и Интернет-технологии для разработки «электронного кейса» как компьютерного средства обучения для самостоятельной работы студентов по иностранным языкам и культурам. Определено содержание обучающей, контролирующей, мотивирующей и информативной функций «электронного кейса» в самостоятельной работе студентов. Описано особенности контента «электронного кейса». Приведены примеры структуры «электронного кейс»" и его содержания для развития умений иноязычного делового письменного общения и умений чтения. Для создания «электронного кейса» целесообразно использовать систему управления обучением Moodle, так как её дидактические возможности позволяют реализовать сформулированные в статье требования к его разработке.
\end{abstract}

Ключевые слова: дистанционные технологии; электронный кейс; иностранные языки и культуры; самостоятельная работа студентов.

\section{(cc) BY-NC-SA}

This work is licensed under Creative Commons Attribution-NonCommercial-ShareAlike 4.0 International License. 